\title{
THE EFFECTIVENESS OF PEDAGOGICAL ECOCRITICISM TO ENHANCE ENVIRONMENTAL AWARENESS IN POST PANDEMIC ERA
}

\author{
Ahmad Iklil Saifulloh ${ }^{1}$, Syafiul Anam ${ }^{2}$ \\ ${ }^{1}$ Univesitas Negeri Surabaya, Surabaya, Indonesia \\ ${ }^{2}$ Universitas Islam Majapahit, Mojokerto, Indonesia \\ *Corresponding Address: ahmad.21008@mhs.unesa.ac.id
}

Received: 1 October 2021 | Approved: 20 December 2021 | Published: 22 Januariy 2022

\begin{abstract}
This study aims to determine the application of pedagogical ecocriticism to increase environmental awareness after two years of the pandemic era forming a passive teaching and learning process. As a quantitative research design, this study tries to reveal the power of pedagogical ecocriticism on environmental awareness. As a pre-experimental research tool, the researcher appointed a parametric statistical test with paired sample $t$-test to determine the significance of defects between pedagogical ecocriticism and environmental awareness. SPSS for Windows (Evaluation Version 22) was used for the analysis. The instrument used is a modified instrument from Gerrad (2012) which includes Pollution, Apocalypse, Position, Pastoral, Future, Wilderness, Dwelling, Animist, Sacred Place, Mysticism, and Earth. Based on statistical analysis, Pearson product-moment was used to correlate pre-test and post-test, and showed correlation values of 0.423 and sig. value is 0.063 . This means that the results are significant; 063 is higher than 005 , and (2-tailed) is .000<0.005 or .000 less than 0.05. It can be concluded that Hypothesis H1 is accepted and H0 is rejected. There are significant results between pedagogical ecocriticism and environmental awareness in the pretest and posttest data. The final result proves that ecocriticism has an important meaning to pay attention to pedagogical in environmental awareness in general
\end{abstract}

Keywords: Pedagogy, Ecocriticism, Environmental Awareness

Abstrak: Penelitian ini bertujuan untuk mengetahui penerapan ekokritik pedagogis untuk meningkatkan kesadaran lingkungan setelah dua tahun era pandemi membentuk proses belajar mengajar secara pasif. Sebagai desain penelitian kuantitatif, penelitian ini mencoba mengungkap kekuatan ekokritik pedagogis terhadap kesadaran lingkungan. Sebagai sarana penelitian praeksperimental, peneliti menunjuk uji statistik parametrik dengan uji t sampel berpasangan untuk menentukan signifikansi cacat antara ekokritik pedagogis dan kesadaran lingkungan. SPSS untuk Windows (Evaluasi Versi 22) digunakan untuk analisis. Instrumen yang digunakan adalah instrumen modifikasi dari Gerrad (2012) yang meliputi Pollution, Apocalypse, Position, Pastoral, Future, Wilderness, Dwelling, Animist, Sacred Place, Mysticism, dan Earth. Berdasarkan analisis statistik, pearson product-moment digunakan untuk mengkorelasikan pre-test dan post-test, dan menunjukkan nilai korelasi 0,423 dan sig. nilai adalah 0,063. Artinya hasil yang signifikan; 063 lebih tinggi dari 005, dan (2-tailed) adalah .000 <0,005 atau .000 lebih kecil dari 0,05. Dapat disimpulkan bahwa Hipotesis $\mathrm{Hl}$ diterima dan $\mathrm{HO}$ ditolak. Terdapat hasil yang signifikan antara ekokritik pedagogis dan kesadaran lingkungan pada data pretest dan posttest. Hasil akhir membuktikan bahwa ecocriticism memiliki arti penting untuk memperhatikan pedagogis dalam kesadaran lingkungan pada umumnya.

Kata kunci: Pedagogi, Ekokritik, Kesadaran Lingkungan 


\section{INTRODUCTION}

Post Pandemic era has begun to trigger industrial movement to grow faster, and the growth of that economic movement in Indonesia mostly relies on the natural resource commodity. The after effect of Natural Resources exploitation tends to be the main problem faced in Indonesia. The problems appear tremendously and have already been realized by the government and massive community in Indonesia, especially the Environment Statistics of Indonesia. For instance, climate change under the amount of water due to Industrial Pumping causes the dry river and swamp every season (Statistics, 2020). Or the air pollution in Indonesia has become the country the third-largest polluter in the world after America and China (Central Bureau of Statistics, 2019).

Arran Stibbe (Stibbe, 2015) mentions the prime paradigm of our destructive behavior toward the environment based on the story we live by. Still, recently the inequality towards consumption and waste increased due to ecological destruction. Another expert tried to redirect the course of humanity, change the stories by which we live (Korten, 2006). We live in a time of social, economic, and ecological unravelin. We believe that the roots of these crises lie in the stories we have been telling ourselves (Edström, 2012). The story we live by becomes the key to how people act toward mass consumption and ecological destruction. The means example of this phenomenon looks a glimpse of a story used in newspaper or social media such as tweeter or hashtag such as Terrorism, and behind it, there is great threat face nowadays. If we scroll down, there is the growth of the economy in Indonesia, and behind it should be getting rich was the goal of society. And this condition makes it our future generations will hard to survive. As Prof will Steven said that "History has shown that civilizations have risen, stuck to the core values and then collapse because they did not change, that's what we are today" (Liverman, 2011). Path of collapse because our goal was economic growth seen humanity as anthropocentrism and economist. We live in the era of mass media information-driven unintentionally hypnotize our way of life. Stories in the minds of numerous people in a society and culture hack how they think, talk and act. So, this research aimed to find a new story through Eco critical Approach to enhance environmental awareness in Post Pandemic Era.

The concrete evidence of the destructive behavior towards ecology was converting Indonesian forests into oil palm forests. Data from the Ministry of Agriculture in (EoF, 2021). States that there are around 3.4 million hectares of illegal oil palm plantations located in forest areas throughout Indonesia. The KPK suspects that there have been trillions of rupiah in losses due to illicit palm oil in forest areas where companies that grow oil palm do not pay taxes to the state. Another fact, Jakarta, as the biggest metropolitan city in Indonesia, was studied by Greenpeace and Air Visual IQ published 
on March 5, 2019, in Saifulloh (Saifulloh, 2019), monitored air quality in Jakarta was ranked first, followed by Hanoi, for the worst air quality, the head of Greenpeace Indonesia, Leonard Simanjuntak.

PT. Freeport has polluted the environment due to mining waste, river water, sediment deposition, metal and hazardous waste content, and the use of protected forests based on data released by the NGO Wahana Lingkungan Hidup (Walhi) and the Environmental Management Performance Program. The company disposes of tailings in Hazardous Toxic waste through the Ajkwa River. This waste has reached the Arafura sea coast. Tailings disposed of by PT. Freeport to the Ajkwa River exceeds the total suspended solids (TSS) quality standard allowed under Indonesian law. PT. Freeport has also polluted the waters at the mouth of the Ajkwa River, contaminated many living things, and threatened the waters with large quantities of acid mine drainage (Astuti, 2018).

According to Greenomics Indonesia's calculations, the cost needed to restore the damaged environment is IDR 67 trillion. PT. Freeport claims that during 1992-2005 the Central Government received a direct profit of US\$ 3.8 billion or approximately Rp. 36 trillion. However, the estimated environmental costs also calculated that Indonesia lost around Rp. 31 trillion. Several media and nongovernmental organizations (NGOs) revealed the mining activities of PT. Freeport has caused increasingly severe environmental damage. Pollution and environmental damage by PT. Freeport had started before 2000. However, the results of the pollution were only released by Walhi in 2006.(Wahana Lingkungan Hidup Indonesia, 2006)

To start a new story was not easy. No one believes, and it is beyond our power to make others believe. So, the only solution was education. That's the reason why the research locus was combining a three-domain of approach; ecology, literature, and education. Emerging ecology and literature was known as Eco-Criticism pioneered by Gregg Gerrad (Garrard, 2004) and covered by education as an umbrella or bridge between how eco-literacy becomes an approach in the learning process. Eco Criticism is a critique of literature to the environment from the perspective of interdisciplinary paradigm which is tried to analyze the environment to find a possible solution and criticize the environmental situation, and how those approaches are implemented in the educational process as mentioned in the book of Teaching ecocriticism and green cultural studies by Gerrad (Garrard, 2012)

Education was one solution in effecting multiple solutions towards ecological awareness. (Saifulloh, 2019) and Indonesia have already been aware by injecting environment curriculum recently in 18 Characters by Ministry of Education and the sixteenth character was Environmental Awareness (Sari et al., 2021). But if we look backward at the historical biography of Indonesian curriculum about the Vocational High School of Adiwiyata concept (Lullulangi et al., 2020). 
Adiwiyata School successfully prove that ecology could be implemented in school, even there still problems remain.

The problem here was an ecological point of view from the teacher who teaches in Adiwiyata School should also be master in environmental proficiency. To do that, this research tends to apply Ecocriticism for higher education. And actually there has been two research building from the previous research or as the improvement of previous research that focused on improving writing skills using a literary ecology approach with the title " The Implementation of Eco Criticism Approach for Healthy Earth and Strengthen the English Writing Skill of Literary Appreciation Class at Islamic University of Majapahit - Mojokerto" (Saifulloh, 2019) and Ecocriticism As The Development of Teaching Materials In Literary Theories And Appreciation Courses (Saifulloh, 2021) and those previous journal also be a steps in teaching Ecocriticism for undergraduate student, an additional review was Level of Environmental Awareness (EAW) among student (Larijani, 2010), Applying ecological concepts to the teaching of literature aims to change young learners' social and individual awareness of environmental challenges (Grimm \& Wanning, 2013) and Teaching Green Cultural Studies and New Media and Teaching Ecocriticism and Cinema (Garrard, 2012).

From those previous sources, the gaps were that methodologies and approaches matched to environmental education are generally not well developed compared with other subject areas. There is a lack of debatable conditions about what might be considered good practice in teaching literature and ecology. The deep understanding of Environmental Awareness through Literature concerning other curriculum subjects was unreliable and, in fact, forced into the curriculum. The use of traditional methods of approach and assessment, which are seen as inappropriate, given the nature of the area of education, and the absence of a suitable alternative, approaches and seems in the cognitive domain. Based on those gaps, the present study aims to identify how effective ecocriticism approach in teaching literature to enhance environmental awareness. It is hypothesized that higher education students differ in their significant influence on environmental awareness through the ecocriticism approach. To solve the gaps, the researcher tried to use specific strategies in education to teach ecocriticism. Strategies, of course, don't come naturally but should be explicitly taught through modeling. There are many models reading strategies, such as Predicting, Visualizing, Questioning, Connecting, Identifying, and Inferring (Retnaningdyah, 2021). And this research focus on the pedagogical paradigm for connecting ecocriticism and pedagogy was the connection. 


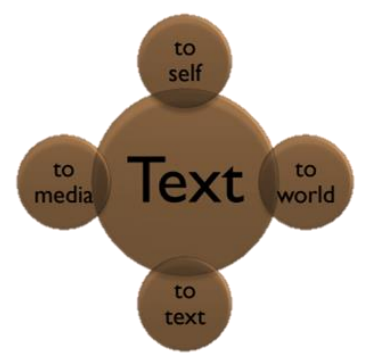

Figure 1. Connection by Louise Rosenblatt's reader-response theory(Woodruff \& Griffin, 2017)

According to reader response theory, connection was separated into four major point of view. First, "Text-to-text" is making connections with other reading. Second, "Text-to-self" involves students connecting what they read to their own lives. Third, "Text-to-world" is connecting their reading to other people and events, and fourth "Text-to-media" is making connections with events, characters, or issues on TV, news, magazine, social media, etc (Retnaningdyah, 2021).

\section{METHOD}

The sample for the present study consisted of 40 higher education students in the 5 th semester from English and Indonesian Department of Islamic University of Majapahit Mojokerto. The tools employed were Environmental Awareness Test (EAW): This test was adopted from Gerrad and focusing on eight different areas of Environmental Awareness Eco Criticism that has several characteristics for affective development and exploring paradigmatic concepts (Garrard, 2004); Pollution, Apocalypse, Position, Pastoral, Future, Wilderness, Dwelling, Animist, Sacred Place, Mysticism, and the Earth. The test was taken twice as Pre Test and Post Test. The test was ten questions representing the pattern of Ecocriticism in certain literary works, so a pre-test to measure the environmental awareness followed by a treatment and a post-test for a single group of students in the fifth semester.

The Instrument was the development of the pattern used in the book written by Gerrad (Garrard, 2012) Teaching Ecocriticism and Green Cultural Studies as described below.

Table 1. Teaching Ecocriticism and Green Cultural Studies

\section{Pre-Test}

No Aspect
Excellent, the Students are able to mention ecological problem that
does not mention a substance or class of substances, but rather a $\quad \begin{gathered}\text { Mean } \\ \text { Score }\end{gathered}$


Good to Average, the Students are able to mention ecological problem that does not mention a substance or class of substances, but rather a normative claim that implies that there is too much of something that is in the wrong place or in the environment it should be but lack in detail.

Fair to Poor, the Students has very poor knowledge and limited experience to mention ecological problem that does not mention a substance or class of substances, but rather a normative claim that implies that there is too much of something that is in the wrong place or in the environment it should be.

Very Poor, the Students are not able to mention ecological problem that does not mention a substance or class of substances, but rather a normative claim that implies that there is too much of something that is in the wrong place or in the environment it should be.

Excellent, the students are able to draw and highlights the dangers of pesticides and sparked intense environmental debate in the twentieth century due to human interference such as nuclear bombs, natural disasters that claimed many living things, terrorism, war, and even epidemics such as the corona virus disease.

Good to Average, the students are able to draw and highlights the dangers of pesticides and sparked intense environmental debate in the twentieth century due to human interference such as nuclear bombs, natural disasters that claimed many living things, terrorism, war, and even epidemics such as the corona virus disease but lack in detail. Fair to Poor, the students are poorly highlights the dangers of pesticides and sparked intense environmental debate in the twentieth century due to human interference such as nuclear bombs, natural disasters that claimed many living things, terrorism, war, and even epidemics such as the corona virus disease.

Very Poor, the students are not able to draw and highlights the dangers of pesticides and sparked intense environmental debate in the twentieth century due to human interference such as nuclear bombs, natural disasters that claimed many living things, terrorism, war, and even epidemics such as the corona virus disease.

Excellent, the students are able to understand the position of the earth

3 Position, as an approach to understanding the environmental crisis in their own way, emphasizing aspects that produce solutions in terms of what they support or threaten the environment. 
Good to Average, the students are able to understand the position of the earth as an approach to understanding the environmental crisis in their own way, emphasizing aspects that produce solutions in terms of what they support or threaten the environment but lack in detail.

Fair to Poor, the students poorly understand the position of the earth as an approach to understanding the environmental crisis in their own way, emphasizing aspects that produce solutions in terms of what they support or threaten the environment.

Very Poor, the students are not able to understand the position of the earth as an approach to understanding the environmental crisis in their own way, emphasizing aspects that produce solutions in terms of what they support or threaten the environment.

Excellent, the students are able to use various techniques to locate and compare multiple environmental conditions in ancient times and now

Good to Average, the students are able to use various techniques to locate and compare multiple environmental conditions in ancient times and now, bbut lack in detail

Pastoral,

Fair to poor, the students poorly use various techniques to locate and compare multiple environmental conditions in ancient times and now Very poor, the students are not able to use various techniques to locate and compare multiple environmental conditions in ancient times and now

Excellent, the students are able to mention about sacred space, a place of refuge, or even a condition that should not be violated

Good to average, the students are able to mention about sacred space, a place of refuge, or even a condition that should not be violated, but

5 Wilderness, lack in detail.

Fair to poor, the students poorly mention about sacred space, a place of refuge, or even a condition that should not be violated

Very poor, the students are not able to mention about sacred space, a place of refuge, or even a condition that should not be violated

Excellent, the students are able to imply the erosion of the long number of humans in terms of death, because humans will inevitably die, and new humans are born again and continue to age like that as

6 Dwelling, endless cycle.

Good to average, the students are able to imply the erosion of the long number of humans in terms of death, because humans will inevitably die, and new humans are born again and continue to age like that as endless cycle, but lack evidence. 
Fair to poor, the students are poorly imply the erosion of the long number of humans in terms of death, because humans will inevitably die, and new humans are born again and continue to age like that as endless cycle.

Very poor, the students are able to imply the erosion of the long number of humans in terms of death, because humans will inevitably die, and new humans are born again and continue to age like that as endless cycle.

Excellent, the students are able to relate the relationship between animals and humans in the humanities discourse is divided between the analysis of animal representations in history and culture, and philosophical considerations about the rights held by animals Good to average, the students are able to relate the relationship between animals and humans in the humanities discourse is divided between the analysis of animal representations in history and culture, and philosophical considerations about the rights held by animals but

7 Animist, lack in evidence.

Fair to poor, the students are poorly relate the relationship between animals and humans in the humanities discourse is divided between the analysis of animal representations in history and culture, and philosophical considerations about the rights held by animals Very poor, the students are not able to relate the relationship between animals and humans in the humanities discourse is divided between the analysis of animal representations in history and culture, and philosophical considerations about the rights held by animals Excellent, the students are able to draw the function or the essence of sacred place and differ them within scientific approach Good to average, the students are able to draw the function or the essence of sacred place and differ them within scientific approach, but

8 Sacred Place, lack of evidence.

Fair to poor, the students are poorly draw the function or the essence of sacred place and differ them within scientific approach Very poor, , the students are not able to draw the function or the essence of sacred place and differ them within scientific approach Excellent, The students are able to visualize the nonliving being such as tree that belongs to something living being, as a home, sanctuary,

9 Mysticism, and treasure, etc

Good to average, The students are able to visualize the nonliving being such as tree that belongs to something living being, as a home, sanctuary, and treasure, etc, but lack in evidence. 
Fair to poor, The students are poorly visualize the nonliving being such as tree that belongs to something living being, as a home, sanctuary, and treasure, etc

Very Poor, The students are not able to visualize the nonliving being such as tree that belongs to something living being, as a home,

sanctuary, and treasure, etc

Excellent, The students are able to define as the same imaginary act in order to understand the earth as a fragile totality of which we are part of it or biocentrism and if we do not protect the earth by grasping the earth is monetary wealth only then we will perish together with the earth.

Good to average, The students are able to define as the same imaginary act in order to understand the earth as a fragile totality of which we are part of it or biocentrism and if we do not protect the earth by grasping the earth is monetary wealth only then we will perish

the Earth, the together with the earth, but lack in evidence

future Fair to poor, The students are poorly define as the same imaginary act in order to understand the earth as a fragile totality of which we are part of it or biocentrism and if we do not protect the earth by grasping the earth is monetary wealth only then we will perish together with the earth.

Very poor, The students are not able to define as the same imaginary act in order to understand the earth as a fragile totality of which we are part of it or biocentrism and if we do not protect the earth by grasping the earth is monetary wealth only then we will perish together with the earth.

Total means

And the treatment procedure of this research was in the post-pandemic era, where the researcher directly met the students. The new atmosphere was the point in this research to know how deep their interest was after a year and a half to start a new story. The first step is giving the students' a Movie and asking them to interpret and analyze it to check their ecocriticism awareness. In this way, they depend only on their background knowledge and experience. The next step is to teach them the main pattern of Ecocriticism in understanding a movie or certain literary works (which cover Pollution, Apocalypse, Position, Pastoral, Future, Wilderness, Dwelling, Animist, Sacred Place, Mysticism, and the Earth) (Garrard, 2012) The last step is to distribute a questionnaire to investigate the effectiveness of Ecocriticism according to the students' points of view. As a means of pre-experimental research, the researcher pointed a statistic parametric test with paired sample t-test to determine the significance 
of defectiveness between Pedagogical Ecocriticism and Environmental Awareness. SPSS for Windows (Evaluation Version 22) was used for the analysis.

\section{Result And Discussion}

\section{Pre-test}

Table 2. Pre-test

Pre-Test

\begin{tabular}{|c|c|c|c|}
\hline No & Aspect & Criteria & $\begin{array}{l}\text { Mean } \\
\text { Score }\end{array}$ \\
\hline 1 & Pollution, & $\begin{array}{l}\text { The Students are able to ecological problem that does not mention a } \\
\text { substance or class of substances, but rather a normative claim that } \\
\text { implies that there is too much of something that is in the wrong place } \\
\text { or in the environment it should be. }\end{array}$ & 90,78 \\
\hline 2 & Apocalypse, & $\begin{array}{l}\text { The students ae able to draw and highlights the dangers of pesticides } \\
\text { and sparked intense environmental debate in the twentieth century due } \\
\text { to human interference such as nuclear bombs, natural disasters that } \\
\text { claimed many living things, terrorism, war, and even epidemics such } \\
\text { as the corona virus } \\
\text { disease. }\end{array}$ & 60,9 \\
\hline 3 & Position, & $\begin{array}{l}\text { The students are able to understand the position of the earth as an } \\
\text { approach to understanding the environmental crisis in their own way, } \\
\text { emphasizing aspects that produce solutions in terms of what they } \\
\text { support or threaten the environment. }\end{array}$ & 60,78 \\
\hline 4 & Pastoral, & $\begin{array}{l}\text { The students are able to use various techniques to locate and } \\
\text { compare multiple environmental conditions in ancient times and now }\end{array}$ & 69,78 \\
\hline 5 & Wilderness, & $\begin{array}{l}\text { The students are able to mention about sacred space, a place of refuge, } \\
\text { or even a condition that should not be violated }\end{array}$ & 61,7 \\
\hline 6 & Dwelling, & $\begin{array}{l}\text { The students are able to imply the erosion of the long number of } \\
\text { humans in terms of death, because humans will inevitably die, and } \\
\text { new humans are born again and continue to age like that as endless } \\
\text { cycle. This }\end{array}$ & 70,33 \\
\hline 7 & Animist, & $\begin{array}{l}\text { The students are able to relate the relationship between animals and } \\
\text { humans in the humanities discourse is divided between the analysis of } \\
\text { animal representations in history and culture, and philosophical } \\
\text { considerations about the rights held by animals }\end{array}$ & 80,99 \\
\hline 8 & Sacred Place, & $\begin{array}{l}\text { the students are able to draw the function or the essence of sacred } \\
\text { place and differ them within scientific approach }\end{array}$ & 68 \\
\hline
\end{tabular}




\begin{abstract}
The students are able to visualize the nonliving being such as tree that
9

Mysticism,

belongs to something living being, as a home, sanctuary, and treasure, etc

10

the Earth, the understand the earth as a fragile totality of which we are part of it or

future biocentrism and if we do not protect the earth by grasping the earth is monetary wealth only then we will perish together with the earth.
\end{abstract}

Total Means
60,88

For the first test, twenty answers are collected by the researchers in accordance with examining the ability of students to analyze and interpret selected movies with the title Life of Pi by Yann Martel. The result shows that the students have ambiguity in analyzing the movie and its relations with Environmental awareness. The primary results show that the students have difficulties understanding comprehensively between Anthropocentrism and Ecocriticism. They assumed based on their past understanding about how humans become the highest chain food on the earth. As proven from one of the student's analysis below;

“PI who eats fish. Previously, PI was a vegetarian, but in an effort to survive he ended up eating fish to eat. This fish comes from the sea which is sourced from the nature where it was at that time"

Ecocriticism means that every living being was breathing in the same sun, equally each other, but some students completely failed to understand that or grasp the main idea of ecocriticism as proven from students work below;

"We can see the theory of eco-criticism in this film which is clearly illustrated in several film scenes. The first scene, Hyena preying on zebras and orangutans. This scene is included in eco criticism, because basically animals will return to their instincts. And this is evidenced by Hyena preying on a zebra that is in pain and an orangutan whose strength is clearly not comparable to that of a hyena"

"PI who is stranded in an acid forest. In this scene, it can be seen that PI finds a treasure on his way, the treasure is the tamarind forest. The acid forest is indeed dangerous for humans, but again because of the forest, PI can also get food stocks for the next few days" 
Table 3. Post-test

Post-Test

$\begin{array}{lll}\text { No Aspect } & \text { Criteria } & \text { Mean } \\ \end{array}$

mention a substance or class of substances, but rather a normative claim that implies that there is too much of something $\quad 90,78$ that is in the wrong place or in the environment it should be.

The students ae able to draw and highlights the dangers of pesticides and sparked intense environmental debate in the

2 Apocalypse, twentieth century due to human interference such as nuclear bombs, natural disasters that claimed many living things, terrorism, war, and even epidemics such as the corona virus disease.

The students are able to understand the position of the earth as an

3 Position, approach to understanding the environmental crisis in their own way, emphasizing aspects that produce solutions in terms of what they support or threaten the environment.

The students are able to use various techniques to locate and

4 Pastoral, compare multiple environmental conditions in ancient times and now

5 Wilderness,

The students are able to mention about sacred space, a place of refuge, or even a condition that should not be violated

The students are able to imply the erosion of the long number of

6 Dwelling, humans in terms of death, because humans will inevitably die, and new humans are born again and continue to age like that as endless cycle. This

The students are able to relate the relationship between animals

$7 \quad$ Animist, and humans in the humanities discourse is divided between the analysis of animal representations in history and culture, and philosophical considerations about the rights held by animals

8 Sacred Place,

the students are able to draw the function or the essence of sacred place and differ them within scientific approach

The students are able to visualize the nonliving being such as tree

9 Mysticism, that belongs to something living being, as a home, sanctuary, and treasure, etc

The students are able to define as the same imaginary act in order to understand the earth as a fragile totality of which we are part of it or biocentrism and if we do not protect the earth by grasping the earth is monetary wealth only then we will perish together with the earth. 
In post-test, almost all of the students could grasp the main idea of Ecocriticism of the movie to understand the environment deeper. The result of the post-test shows that the students could grasp the idea of ecocriticism by Gerrad (which is covering Pollution, Apocalypse, Position, Pastoral, Future, Wilderness, Dwelling, Animist, Sacred Place, Mysticism, and the Earth) (Garrard, 2012) The students are able to analyze those elements and relate the idea of ecocriticism in their daily life. For example, they could say that animals couldn't be locked in the zoo because the true home was the forest (earth). And the zoo function was categorized as a dwelling (temporary places for the tiger called Richard Parker. The dwelling was the condition when a living being will lose their will of life because of their lazy time-consuming leisure time by spoon-feeding in the zoo. In the addition, they have their own personal connection with other sources such as circus as mentioned below;

In this film, it is told that the PI family built a private zoo owned by their family. We certainly often see this case about a zoo that was built in the middle of the city. Animal life in this zoo is certainly not in accordance with their life in the wild. When in nature they live freely without being locked up, while in the zoo the animals are locked and sometimes even employed for the circus, which is included in animal exploitation. So the construction of a zoo in the middle of the city is considered not good for the animal.

Another prove was the apocalyptical point of view deliver by the students, such as

This film tells the story of Pi Patel, the son of zero keeper. Living in Pondicherry, India, they then moved to Canada by boarding freighter. Apocalyptical point of view represent by the ship damage and storms leave Pi stranded in the middle of the Pacific Ocean with a zebra, hyena, orang utan and tiger named Richard Parker. They try to survive in the midst of the fierce sea.

The students mention about the position of animal equally as human being;

PI argues that "animal too" have souls. PI's opinion was opposed by his father who argued that animals could never be human's friends. Animals have souls and this is shown by how much love the mother gives to her child or pet to employer.

The final point is, the students are effectively narrate and point the ecocriticism by Gerrad (Garrard, 2004) and for more detail information, the students also has a chance to deliver a presentation about their analysis and also some debatable argument about ecocriticism trough this link; https://bit.ly/3plosOt 


\section{Statistical Analysis}

Statistical descriptive shows that the total sample was 40 students. The means score of the pretest was 71.3000 and posttest shows 89.2500 , as mentioned below;

Table 4. Paired sample statistic

$\begin{array}{lcc} & \text { Mean } & \text { Std. Deviation } \\ \text { Pretest } & 71.3000 & 8.99181 \\ \text { Posttest } & 89.2500 & 5.37905\end{array}$

Pearson product-moment was used to correlate the pre-test and post-test, and it shows that the correlation value was .423 and sig. value was .063. Its means that the significant result; 063 was higher than 005. It obviously concluded that between pre-test and post-test has no correlation. As mentioned in the table below;

Table 5. Paired sample correlation

$\begin{array}{lcc} & \text { Correlation } & \text { Sig. } \\ \text { Pretest \& Posttest } & .423 & .063\end{array}$

Those table below means that sig. (2-tailed) was .000 $<0,005$ or .000 is smaller than 0,05 . It can be concluded that Hypothesis $\mathrm{H}^{1}$ was accepted and $\mathrm{H}^{0}$ was rejected. There is significance result between pedagogical Ecocriticism and Environmental Awareness at the data of Pre-test and Post Test.

Table 6. Paired sample Test

$\begin{array}{lcc} & \text { Std. Deviation } & \text { Sig. (2-tailed) } \\ \text { Pair 1 Pretest \& } & 8.30013 & .000 \\ \text { Posttest } & & \end{array}$

Students taught using the pedagogical Ecocriticism strategy with a specification of 4 connections have a score of environmental awareness in appreciating literary works that is better in the posttest than the score at the pretest. Based on a related theory from Gregg Gerrad (2012) in his book Teaching Ecocriticism and Green Cultural Studies that ecological literary criticism makes students more focused and understands the importance of the environment. In addition, the paradigm that built before and after treatment was very good in understanding the anthropocentric to ecological paradigm shift.

The results show that the average pretest is 71.38 and the posttest average is 89.25 . The result shows that the significance of students' environmental awareness is higher than 0.05 . The pretest and posttest show that the correlation value was .423 and sig. value was .063. Its means that the significant result, 063 was higher than 005 . So, it means that $\mathrm{H} 0$ is accepted and $\mathrm{H} 1$ is rejected. 
The researcher found that environmental literature criticism using the four pedagogical strategy makes it easier for students to understand the material because they can understand the context of literary works. The design of four connections connects and compares students' knowledge in literary works and reality. Students also find it easier to remember what characteristics of ecological literary works.

In data analysis, the researcher pointed a statistical parametric test with paired sample t-test from SPSS 22. The t-test result of p-value was 0.000 lower than the significant level (0.05). If the pvalue < from the significant level $(0.05), \mathrm{Ha}$ is accepted, and $\mathrm{H} 0$ is rejected. The result shows that sig. (2-tailed) was .000 < 0.005 or .000 is smaller than 0.05. It can be concluded that Hypothesis H1 was accepted, and $\mathrm{H} 0$ was rejected. There is a significant result between pedagogical Ecocriticism and Environmental Awareness at the data of Pre-test and Post Test.

\section{CONCLUSION}

This research introduced the techniques of pedagogical ecocriticism to the students as an anchor to pull the environmental awareness. The teacher has an important and heavy role in forming the new paradigm shift of the story that we live by. The teacher is the bridge to bring the future student to attach the environment as part of their teaching carefully. Even there are so many challenges in the informal system of education. However, the government still tried to emphasize give the initiative to make Environmental Education an integral part of formal education through its national curriculum framework in Adiwiyata School and 16th character of National Education. The regulation is being made to drive in integrating environmental paradigm into the current curriculum nowadays, developing new approaches, preparing indicator and the outcome material for significant putting into practice of Environmental Education in the formal system.

\section{REFERENCES}

Astuti, A. D. (2018). Implikasi Kebijakan Indonesia Dalam Menangani Kasus Pencemaran Lingkungan Oleh PT. Freeport Terhadap Keamanan Manusia Di Mimika Papua. Journal of International Relations, 4(3), 547-555.

Central Bureau of Statistics. (2019). Indonesian Environmental Statistics 2019. Badan Pusat Statistik, 1-224. https://www.bps.go.id/publication/2018/12/07/d8cbb5465bd1d3138c21fc80/statistiklingkungan-hidup-indonesia-2018.html

Edström, H. (2012). Understanding uncivilisation. May, 1-55. 
EoF. (2021). Seminar Nasional “ Sawit Sebagai Tanaman Hutan di IPB ,” Forum Akademis untuk Merusak Hutan. November, 1-5.

Garrard, G. (2004). Ecocriticism (the New Critical Idiom). In London and New York: Routledge Taylor \& Francis Group (Vol. 53, Issue 9).

Garrard, G. (2012). Teaching ecocriticism and green cultural studies. In Teaching Ecocriticism and Green Cultural Studies. https://doi.org/10.1057/9780230358393

Grimm, S., \& Wanning, B. (2013). Cultural Ecology and the Teaching of Literature Teaching Literature within an Ecocritical Framework.

Korten, D. (2006). Change the Story, Change the World. 1-7.

Larijani, M. (2010). Assessment of Environmental Awareness among Higher Primary School Teachers. Journal of Human Ecology, 31(2), 121-124. https://doi.org/10.1080/09709274.2010.11906302

Liverman, K. R. W. S. D. (2011). Climate Change: glOBal Risks, Challenges and deCisiOns. Cambridge University Press.

Lullulangi, M., Arfandi, A., Kalengkongan, M. J., Hamzah, Salahuddin, M., Pali, O., \& Aris. (2020). PEMBELAJARAN LINGKUNGAN HIDUP YANG KREATIF DAN INOVATIF.

Retnaningdyah, P. (2021). Text connections.

Saifulloh, A. I. (2019). The Implementation of Ecocriticism Approach for Healthy Earth and strengthen the English Writing Skill of Literary Appreciation Class. IJOELL, 01(02), 10-17.

Saifulloh, A. I. (2021). Ecocriticsm as the Development of Teaching Materials in Literary Theories and Appreciation Courses. International Journal of English Education and Linguistics (IJoEEL), 3(1), 1-9. https://doi.org/10.33650/ijoeel.v3i1.1752

Sari, N. P., Makaria, E. C., Rochgiyanti, R., \& Setiawan, M. A. (2021). Environment Care Character Education as a Flood Disaster Management Effort. AL-ISHLAH: Jurnal Pendidikan, 13(2), 1471-1478. https://doi.org/10.35445/alishlah.v13i2.923

Statistics, S. of E. (2020). Environtment Statistics of Indonesia.

Stibbe, A. (2015). Ecolinguistics: Language, Ecology and the Stories We Live. In Southern African $\begin{array}{llll}\text { Linguistics and } \quad \text { Anguage } & \text { Routledge. }\end{array}$ https://doi.org/10.2989/16073614.2018.1547983

Wahana Lingkungan Hidup Indonesia. (2006). Dampak Lingkungan Hidup Operasi Pertambangan 
Qalamuna - Jurnal Pendidikan, Sosial, dan Agama | Vol. 14 No. 1 (2022)

Tembaga.

Woodruff, A. H., \& Griffin, R. A. (2017). Reader response in secondary settings: increasing comprehension through meaningful interactions with literary texts. Texas Journal of Literacy Education, 5(2), p.108-116. 
THE EFFECTIVENESS OF PEDAGOGICAL ECOCRITICISM TO ENHANCE ENVIRONMENTAL ... Ahmad Iklil Saifulloh, Syaiful Anam 